\title{
Application of Alum Sludge in Phosphate Phosphorus Removal from Contaminated Water
}

\author{
B. Ojha ${ }^{1}$ ， R. K. Sharma ${ }^{2}$ ， I. M Amatya ${ }^{3}$ \\ ${ }^{1,3}$ Department of Civil Engineering, Pulchowk Campus, Institute of Engineering TU, Nepal \\ ${ }^{2}$ Department of Applied Science, Pulchowk Campus, Institute of Engineering TU, Nepal \\ Corresponding author: ${ }^{1072 m s n 904 . b i n i t @ p c a m p u s . e d u . n p ~}$
}

Received: Dec 21, 2018

Revised: Feb 22, 2019

Accepted: Feb 26, 2019

\begin{abstract}
This study determines application of alum sludge in phosphate phosphorus $\left(\mathrm{PO}_{4}^{3-} / \mathrm{P}\right)$ removal from contaminated water. For the study the alum sludge was collected from Mahankal Water Treatment Plant and dewatered by drying in micro oven under $105^{\circ} \mathrm{C}$ and crumble to average particle size of $5 \mathrm{~mm} .10 .7 \mathrm{ppm}$ Synthetic $\mathrm{PO}_{4}^{3-} / \mathrm{P}$ solution was prepared by dissolving $\mathrm{Na}_{2} \mathrm{HPO}_{4} \cdot 2 \mathrm{H}_{2} \mathrm{O}$. Batch test was conduct to determine the $\mathrm{PO}_{4}^{3-}-\mathrm{P}$ removal efficiency and to develop adsorption isotherm. The phosphorus removal efficiency was tested for $8 \mathrm{~g}, 16 \mathrm{~g}, 24 \mathrm{~g}, 32 \mathrm{~g}$ and $40 \mathrm{~g}$ alum sludge per $\mathrm{L} \mathrm{PO}_{4}^{3-} / \mathrm{P}$ solution for different contact time. The $\mathrm{PO}_{4}^{3-} / \mathrm{P}$ content in the sample solution was determine by L-Ascorbic Acid method using Spectrophotometer (Shimadzu UVmini-12400) in the lab of Pulchowk Campus, Institute of Engineering Tribhuvan University. The $\mathrm{PO}_{4}^{3-} / \mathrm{P}$ removal efficiency was found to be $95.5 \%$ for $8 \mathrm{~g} / \mathrm{L}$ dosing and $98.4 \% \%$ for $40 \mathrm{~g} / \mathrm{L}$. The contact time decreases with increase in dosing $50 \mathrm{~min}$ for $8 \mathrm{~g} / \mathrm{L}$ and $5 \mathrm{~min}$ for $40 \mathrm{~g} / \mathrm{L}$ dosing. The adsorption process best fit Freundlich isotherm with higher correlation coefficient $\left(\mathrm{R}^{2}\right.$ $=0.87)$ and Freundlich intensity parameter $(1 / \mathrm{n})$ less than unit $(1 / \mathrm{n}=0.76)$ upto $50 \mathrm{~min}$ contact time and beyond 50min contact time intensity parameter $(1 / \mathrm{n})$ greater than unit. The adsorption capacity determine from isotherm indicate increase in adsorption capacity with increase in dosing. The adsorption capacity increases from 1.39 to $28.07 \mathrm{mg} / \mathrm{g}$ when contract time varies from 1 to $120 \mathrm{~min}$.
\end{abstract}

Key words: Dewater alum sludge, phosphate phosphorus, adsorption isotherms, batch test

\section{Introduction}

During early period, when population was low, the waste produce was limited and was not complex. Most of the waste generated were from domestic activities and were organic in nature. But with the increase in the pace towards development and rapid growth of population, the demand and need of people are also increasing rapidly. Agriculture and the urban activities are the major sources of nutrient which get released in the environment [3]. Particularly, the waste water from farmland, textile, leather industry etc. contain phosphorous and nitrogen which are not easily degradable. Excessive nitrogen and phosphorus in waste water will cause eutrophication and affect the aquatic ecosystem. The phosphate present in the contaminated water can be removed using physical chemical and biological process [7]. The phosphorus present in the wastewater is removed by 
the process of sedimentation, filtration, adsorption, plant and microbial uptake. Plant uptake, microorganism is an important sink for $\mathrm{P}$ in short term whereas substrate is the main sink of the $\mathrm{P}$ [6]. Often the P removal traditional constructed wetland which uses gravel and sand as the main substrate is found to be poor due to their low $\mathrm{P}$ adsorption capacity [8].

The alum sludge is the byproduct of the water treatment process using Alum $\left(\mathrm{Al}_{2}(\mathrm{SO})_{4} \cdot 18 \mathrm{H}_{2} \mathrm{O}\right)$ as coagulant. It has estimated that worldwide aluminum water treatment sludge to be $10,000 \mathrm{t} /$ day and keep on increase until the aluminum compounds remain major coagulant in water treatment industry [5]. The sludge has a gelatinous and typically contains high concentrations of aluminum with a mixture of organic and inorganic materials and hydroxide precipitation [2]. Alum sludge is derived from the residual of raw water which contains mainly turbidity, color and humic material with no toxic substances in most case [11]. In the present contest the alum sludge were being disposal as the waste in landfill site. Therefore, sustainable management of such sludge continues to become an increasing concern in the water industry. In this regards the alum sludge can be use for the removal of phosphorus from the wastewater and various study has shown the varying degree of phosphorus removal. The use of alum sludge not only helps to remove the phosphate phosphorus $\left(\mathrm{PO}_{4}^{3-} / \mathrm{P}\right)$ but also effective in management of alum sludge, which is the major concern of water treatment industry.

\section{Methodology}

For the study the alum sludge was collected from Mahankal Water Treatment Plant and dewatered by drying in micro oven under $105^{\circ} \mathrm{C}$ and crumble to average particle size of $5 \mathrm{~mm} .10 .7 \mathrm{ppm}$ Synthetic $\mathrm{PO}_{4}^{3-} / \mathrm{P}$ solution was prepared by dissolving $\mathrm{Na}_{2} \mathrm{HPO}_{4} \cdot 2 \mathrm{H}_{2} \mathrm{O}$. Batch test was conducted to determine the $\mathrm{PO}_{4}^{3-} / \mathrm{P}$ removal efficiency of alum sludge and compare the removal efficiency with increase in dosage and contact time. $250 \mathrm{~mL}$ of $10.7 \mathrm{ppm} \mathrm{PO}_{4}^{3-} / \mathrm{P}$ was taken in conical flask and per-weighted amount of Dewatered Alum Sludge (DWAS) (2, 4, 6, 8 and 10g) was added in the conical flask. Then the conical flask was placed in the orbital shaker. After the specific contact time, $1,2,5,10,15,20,30,40,50,60,75,90,105$, and $120 \mathrm{~min}$, sample was withdrawn from flask and filtered through whatman filter paper (cat $\mathrm{No} 1000$ 125) and the $\mathrm{PO}_{4}^{3-/ P}$ concentration was determined by L-Ascorbic Acid method using Spectrophotometer (Shimadzu UVmini-12400) in the lab of Pulchowk Campus, Institute of Engineering Tribhuvan University.

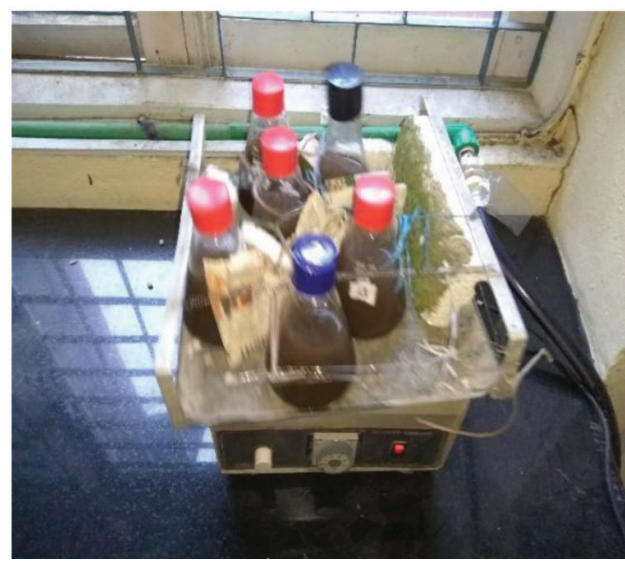

Fig. 1: Orbital Shaker

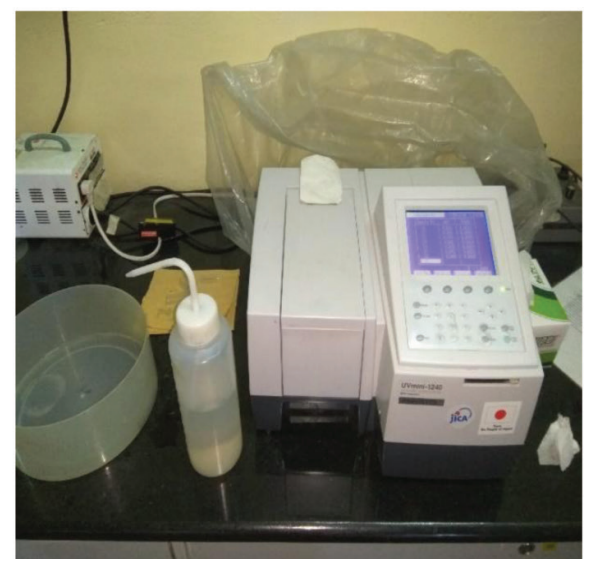

Fig. 2: Spectrophotometer 


\section{Results and Discussions}

\subsection{Results}

The results and discussions were based on the outcome of the lab experiment conducted in the laboratory of Institute of Engineering, Pulchowk Engineering Campus, Tribhuvan University. The $\mathrm{PO}_{4}{ }^{3-} / \mathrm{P}$ removal efficiency of DWAS were determine for the different contact time $(1,2,5,10,15$, $20,30,40,50,60,75,90,105$, and $120 \mathrm{~min})$ and also for different dosing $(8,16,24,32$ and $40 \mathrm{~g} / \mathrm{L})$. The experiment was conducted with $10.7 \mathrm{ppm}$ initial concentration of $\mathrm{PO}_{4}^{3-} / \mathrm{P}$ synthetic solution.

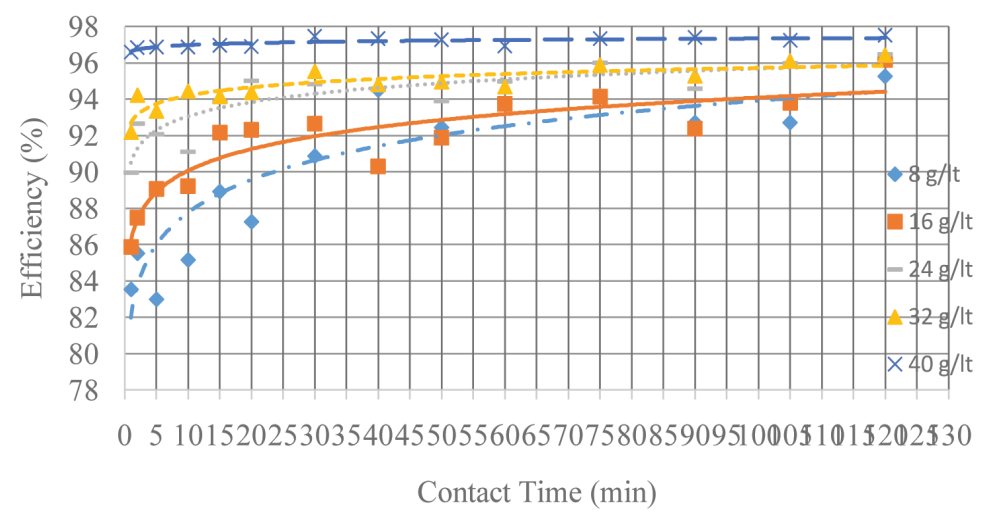

Fig. 3: $\mathrm{PO}_{4}^{3-} / \mathrm{P}$ removal efficiency for different dosing and contact time

The removal efficiency of alum sludge varies from $83.5 \%$ to $95.3 \%, 85.9 \%$ to $96.2 \%, 89.9 \%$ to $96.5 \%, 92.2 \%$ to $96.4 \%$ and $96.6 \%$ to $98.6 \%$ for doing $8 \mathrm{~g} / \mathrm{L}, 16 \mathrm{~g} / \mathrm{L}, 24 \mathrm{~g} / \mathrm{L}, 32 \mathrm{~g} / \mathrm{L}$ and $40 \mathrm{~g} / \mathrm{L}$ respectively when contact time varies from 1 to $120 \mathrm{~min}$. Although the study was conducted for different contact time varying from 1 to 120 min but for the $90 \%$ removal of $\mathrm{PO}_{4}^{3-} / \mathrm{P}$ from the solution effective contact time was determine. As per Amatya [1] contact time is calculated as the required for $90 \%$ adsorption of the amount adsorbed in equilibrium time.

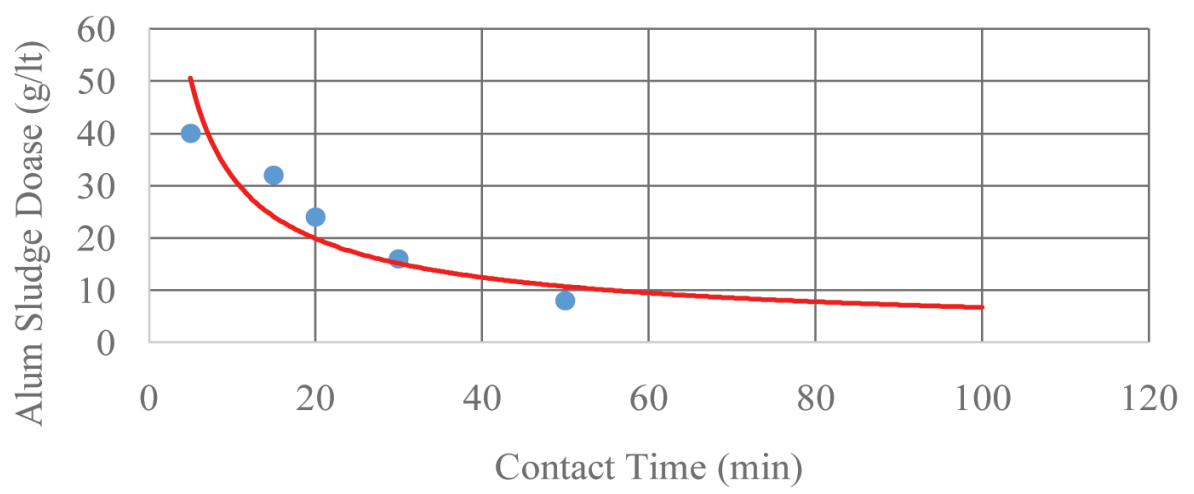

Fig. 4: Alum sludge dosing and contact time relationship

The graph shows the relation between alum sludge dosing and contact time. It shows contact time decreases with increase in dosing. But increasing dosing beyond $30 \mathrm{~g} / \mathrm{L}$ does not decrease 
the contact time effectively and decreasing of dosing beyond $10 \mathrm{~g} / \mathrm{L}$ increase the contact time sharply. So, the optimum dosing range of DWAS is between 10 to $30 \mathrm{~g} / \mathrm{L}$. To determine the $\mathrm{PO}_{4}^{3-} / \mathrm{P}$ adsorption capacity of DWAS adsorption isotherm was plotted. The data best follow the freundlich isotherm and same was used. The Fig. 5 shows the freundlich isotherm at $50 \mathrm{~min}$ contact time and similar isotherms were also plotted for contact time 1, 2, 5, 10, 15, 20, 30, 40, 60, 75, 90, 105, and $120 \mathrm{~min}$.

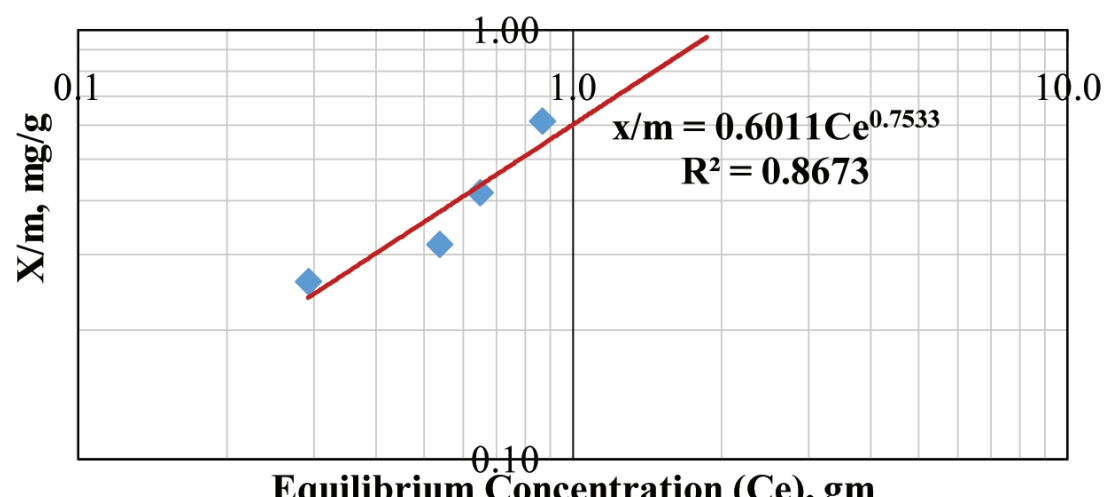

Fig. 5: Freundlich Isotherm curve at 50 min Contact time

Table 1: Freundlich adsorption capacity factor and intensity parameter

\begin{tabular}{|c|c|c|c|c|}
\hline $\begin{array}{c}\text { Freundlich } \\
\text { Contact } \\
\text { Time (min) }\end{array}$ & $\mathrm{Kf}$ & $1 / \mathrm{n}$ & $\mathrm{qm}$ & $\mathrm{R}^{2}$ \\
\hline 1 & 0.40 & 0.53 & 1.39 & 0.84 \\
\hline 2 & 0.47 & 0.60 & 296 & 0.95 \\
\hline 5 & 0.47 & 0.62 & 2.03 & 0.83 \\
\hline 10 & 0.47 & 0.61 & 2.00 & 0.88 \\
\hline 15 & 0.59 & 0.80 & 3.94 & 0.76 \\
\hline 20 & 0.65 & 0.86 & 4.96 & 0.75 \\
\hline 30 & 0.69 & 0.81 & 4.61 & 0.89 \\
\hline 40 & 0.56 & 0.66 & 2.64 & 0.89 \\
\hline 50 & 0.60 & 0.75 & 3.58 & 0.87 \\
\hline 60 & 0.77 & 1.02 & 8.62 & 0.67 \\
\hline 75 & 0.99 & 1.10 & 13.43 & 0.85 \\
\hline 90 & 0.65 & 0.78 & 4.18 & 0.88 \\
\hline 105 & 0.98 & 1.12 & 17.36 & 0.82 \\
\hline 120 & 5.06 & 2.40 & 28.07 & 0.59 \\
\hline
\end{tabular}

qm Freundlich maximum adsorption capacity $(\mathrm{mg} / \mathrm{g})$,

Kf Freundlich capacity factor, (mg adsorbate/g alum sludge) $(\mathrm{L} \text { water } / \mathrm{mg} \text { adsorbent })^{\wedge}(1 / \mathrm{n})$, $1 / n=$ Freundlich intensity parameter. 
As per Fierro et al. [4] adsorption phenomenon is considered to be satisfactory when the value of $\mathrm{n}$ is in between 1 to 10 . The Table 1 shows the value of $1 / \mathrm{n}$ is less than unit up to 50 min contact time, i.e. value of $\mathrm{n}$ is greater than 1 . Beyond 50 min contact time the value on $1 / \mathrm{n}$ is greater than unit, $i$. e. value of $\mathrm{n}$ is less than unit indication unfavorable adsorption phenomenon.

\subsection{Discussion}

The removal efficiency of dewatered alum sludge varies from $83.5 \%-95.3 \%$ for $8 \mathrm{~g} / \mathrm{L}$ dosing. Similarly the removal efficiency for $16,24,32$, and $40 \mathrm{~g}$ alum sludge/L solution varies from $85.9 \%$ $-96.2 \%, 89.9 \%-96.5 \%, 92.2 \%-96.4 \%$ and $96.6 \%-98.6 \%$ respectively. The result agreed with the result of Zahari et al. [10] which indicate the P removal efficiency of $91.5 \%$ and $92.3 \%$ in synthetic $\mathrm{PO}_{4}^{3-}$ solution. During the study it was found, the increase in the dosing decrease the $\mathrm{P}$ uptake by the alum sludge decrease. As the dosing increase from 8 to $40 \mathrm{~g} / \mathrm{L} \mathrm{PO}_{4}^{3-} / \mathrm{P}$ uptake decreases from 1.2 to $0.3 \mathrm{mg} \mathrm{P} / \mathrm{g}$ dewater alum sludge. It might be due to decrease in adsorption site due to aggregation of the adsorbent and also the adsorption amount and the mass of adsorbent has inverse relationship. The study indicated the adsorption capacity of alum sludge from Mahankal Water Treatment Plant is $3.6 \mathrm{mg} / \mathrm{g}$ alum sludge at contact time of $50 \mathrm{~min}$. The result is in good agree with in the result of Yang et al. [9] who claim the adsorption capacity of 0.7 to $3.5 \mathrm{mg} / \mathrm{g}$ when $\mathrm{pH}$ range from 9-4.3. The adsorption capacity of alum sludge increases from 1.39 to $28.07 \mathrm{mg} / \mathrm{g}$ when contract time varies from 1 to $120 \mathrm{~min}$.

\section{Conclusion}

The research was conducted to determine the possible use of alum sludge in $\mathrm{PO}_{4}^{3-} / \mathrm{P}$ removal from contaminated water. The work concluded the application of alum sludge in $\mathrm{PO}_{4}^{3-} / \mathrm{P}$ removal. The study shows $\mathrm{PO}_{4}^{3-} / \mathrm{P}$ removal efficiency upto $98.6 \%$ at contact time $120 \mathrm{~min}$ for $40 \mathrm{~g} / \mathrm{L}$ dosing. The $\mathrm{PO}_{4}^{3-} / \mathrm{P}$ adsorption capacity of DWAS was found to be varies between 1.39 to $28.07 \mathrm{mg} / \mathrm{g}$ from freundlich isotherm. The adsorption isotherm shows the favorable adsorption upto 50min contact time. The relation between dosing and contact time shows the optimum dosing range of DWAS is 10 to $30 \mathrm{~g} / \mathrm{L}$. The present works also reveal the alternative use of alum sludge which was consider as waste. So, the alum sludge produced from water treatment industry can be used as cost effective media for the treatment of contaminated water which further help in management of alum sludge.

\section{References}

[1] Amatya IM (2002), Total chlorine adsorption by locally available wood charcoal, MSc Thesis, Department of Civil Engineering, IOE, Tribhuvan University, Nepal.

[2] Babatunde AO, Zhao YQ, O'neill M and O'sullivan B (2008), Constructed wetland for environmental pollution control: A review of developments, research and practice in Ireland. Environment International, 34(1): 116-126.

[3] Carpenter SR, Caraco NF, Correll DL, Howarth RW, Sharpley AN and Smith VH (1998), Non point pollution of surface waters with phosphorus and nitrogen, Ecological applications, 8(3): 559-568.

[4] Fierro V, Torné-Fernández V, Montané D and Celzard A (2008), Adsorption of phenol onto activated carbons having different textural and surface properties, Microporous and mesoporous materials, 111(1-3): 276-284.

[5] Nansubuga I, Banadda N, Babu M, Verstraete W and Van de Wiele T (2013), Effect of polyaluminium chloride water treatment sludge on effluent quality of domestic wastewater 
treatment. African Journal of Environmental Science and Technology, 7(4): 145-152.

[6] Sakadevan K and Bavor HJ (1998), Phosphate Adsorption Characteristics of Soil, Slags and Zeolite to be used as substrates in constructed wetland system, Wet. Res, 32(2): 393-399.

[7] Storm, Peter F (2006), Technology to removal phosphorus from wastewater, New Brunswick, New Jersey: Rustgers University, 18.

[8] Wu S, Austin D, Liu L and Dong R (2011), Performance of integrated household constructed wetland for domestic wastewater treatment in rural areas, Ecological Engineering, 37(6): 948954.

[9] Yang Y, Tomlinson D, Kennedy S and Zhao YQ (2006), Dewater alum sludge: a potential adsorption for phosphorus removal, Water Science Technology, 54(5): 207-213.

[10] Zahari NM, Hua CK and Sidek LM (2015), Influence of Contact Time on Effectiveness of Recycle Alum Sludge as Pollutant Removal, Journal of Energy and Environment, 7(1): 1-4.

[11] ZhaoYQ, Zhao XH and Babatunde AO (2009), Use of dewatered alum sludge as main substrate in treatment reed bed receiving agricultural wastewater: long-term trial. Bioresource Technology, 100(2): 644-648. 